\title{
ASSESSMENT OF HEAVY METAL CONTAMINATION IN SOIL AND WHEAT (Triticum Aestivum L.) PLANT AROUND THE ÇORLU-ÇERKEZKOY HIGHWAY IN THRACE REGION
}

\author{
F. EKMEKYAPAR \\ T. ŞABUDAK ${ }^{2}$ \\ G. ŞEREN ${ }^{3}$
}

Received: 25/08/11

Accepted: 10/01/12

\author{
${ }^{1}$ Namik Kemal University, Faculty of Corlu Engineering, \\ Department of Environmental Engineering, 59860 Tekirdag, Turkey \\ ${ }^{2}$ Namik Kemal University, Faculty of Science and Art, \\ Department of Chemistry, Tekirdag, Turkey \\ ${ }^{3}$ Trakya University, Faculty of Science and Art, \\ Department of Chemistry, 22030, Edirne, Turkey
}

\begin{abstract}
Pollution caused by traffic activities is increasingly becoming a great threat to human health in the region of Thrace in north-west of Turkey. Thirty six soil and plant samples were collected from the vicinity of Çorlu-Çerkezköy Highway. The samples were taken at distances of, 1, 25, 50, 100, 250 and $500 \mathrm{~m}$ from the highway. The each plant sample was divided into two subsamples. One subsamples of each plant was washed with with distilled water, while other part was not washed and were analyzed without any washing. All samples were analyzed for their heavy metal concentrations ( $\mathrm{Pb}, \mathrm{Zn}, \mathrm{Cd}, \mathrm{Cu}, \mathrm{Ni}, \mathrm{Mn}, \mathrm{Cr}$ and $\mathrm{Fe})$. The results showed that the soils in the study area were polluted by $\mathrm{Pb}$. The lead concentration in the soil showed values from $19 \pm 0.2 \mathrm{mg} \mathrm{kg}$ to $351 \pm 0.3 \mathrm{mg} \mathrm{kg}^{-1}$ and found to be higher than the allowable maximum limits in soils. The manganese levels of soils were slightly high and varied from $182 \pm 0.1 \mathrm{mg} \mathrm{kg}^{-1}$ to $806 \pm 0.1 \mathrm{mg} \mathrm{kg}^{-1}$. In this study, metal concentrations of unwashed plant samples were higher than those of the washed ones. This study indicated that the heavy metal contents decreased with increasing distances from the highway in unwashed plants.
\end{abstract}

KEYWORDS: traffic pollution, metal concentration, food safety, human health.

\section{INTRODUCTION}

Heavy metals are currently of much environmental concern. They are harmful to humans, animals and are susceptible to bioaccumulation in the food chain. Heavy metals may come from many different sources in urban areas. Atmospheric pollution is a major contributor to heavy metal contamination in topsoils (Kelly et al., 1996).

One of the most important sources of air pollution is vehicle emission. Metals such as $\mathrm{Fe}, \mathrm{Cu}$ and $\mathrm{Zn}$ are essential components of many alloy, pipes, wires and tires in motor vehicles and are released into the roadside environment as a result of mechanical abrasion (Jaradat et al., 2005). The metallic pollutants in the air eventually precipitated on the ground surface depending on wind flow patterns and increased their concentration in adjacent areas (Harrison et al., 1981). Therefore, the enrichment of heavy metals in soils nearby roadsides has been reported in several studies (Norrstrom and Jacks, 1998; Charlesworth et al., 2003; Turer and Maynard, 2003; Viard et al., 2004). In such studies the heavy metal concentrations were compared according to traffic volumes and distance from (Piron-Frenet et al., 1994; Sezgin et al., 2003; Kalavrouziotis et al., 2006).

Heavy metals are known as non-biodegradable, and persist for long durations in aquatic as well as terrestrial environments. They might be transported from soil to ground waters or may be taken up by plants, including agricultural crops. For this reason, the knowledge of metal-plant interactions is also important for the safety of the environment. Recently, a number of studies have drawn attention 
to the heavy metal accumulation in plants (Shallari et al., 1998; Yoon et al., 2006; Salah and Barrington, 2006; Kalavrouziotis et al., 2007a; 2007b; Jamali et al., 2009).

In today's environment, food safety and quality are most important in human health problems, especially in the developing country. For this reason, food safety has been recognized as such by FAO/WHO/EU Codex Alimentarius Commission. Turkey has strived to become a full member in EU since 1960. But, there are no enhanced regulations for food safety. Management systems are now built on a detailed understanding in Turkish Agriculture Ministry. Safety Regulation on food has been developing in harmony with the EU regulations. Ensuring food safety depends on effective control measures.

In the light of all these recent developments, the aim of this work is to assess the heavy metal contamination in wheat plant and agricultural soils in Thrace region. Specifically, there is no record of any information on the heavy metals contents of agricultural soils. Consequently, back-ground of heavy metal concentrations of the soils studied has not known. More research is needed to clarify this region. In this study, the heavy metal contamination in soil and plant, as one each function of a distance and direction, were evaluated. The effects of traffic pollution on wheat plant were exposed.

\section{MATERIALS AND METHODS}

\subsection{Study Area Discription}

Corlu and Cerkezkoy are industrial towns in Thrace region have been highly urbanized and industrialized in last decades. Textile factories (21 units), dye factories (2 units), ready mixed concrete ( 2 units) and a metal factory (1 unit) are active in the study area. The industrialization has brought up the population density. The products of industry, raw materials are transported to factories using Corlu-Cerkezkoy Highway. Traffic density is quite high due to the links with Istanbul Highway. There are 29543 registered motor vehicles in Corlu and 6299 in Cerkezkoy are registered. For more than 20 years, vehicles have been exhaust fumes in this area without any regulations (Figure 1).
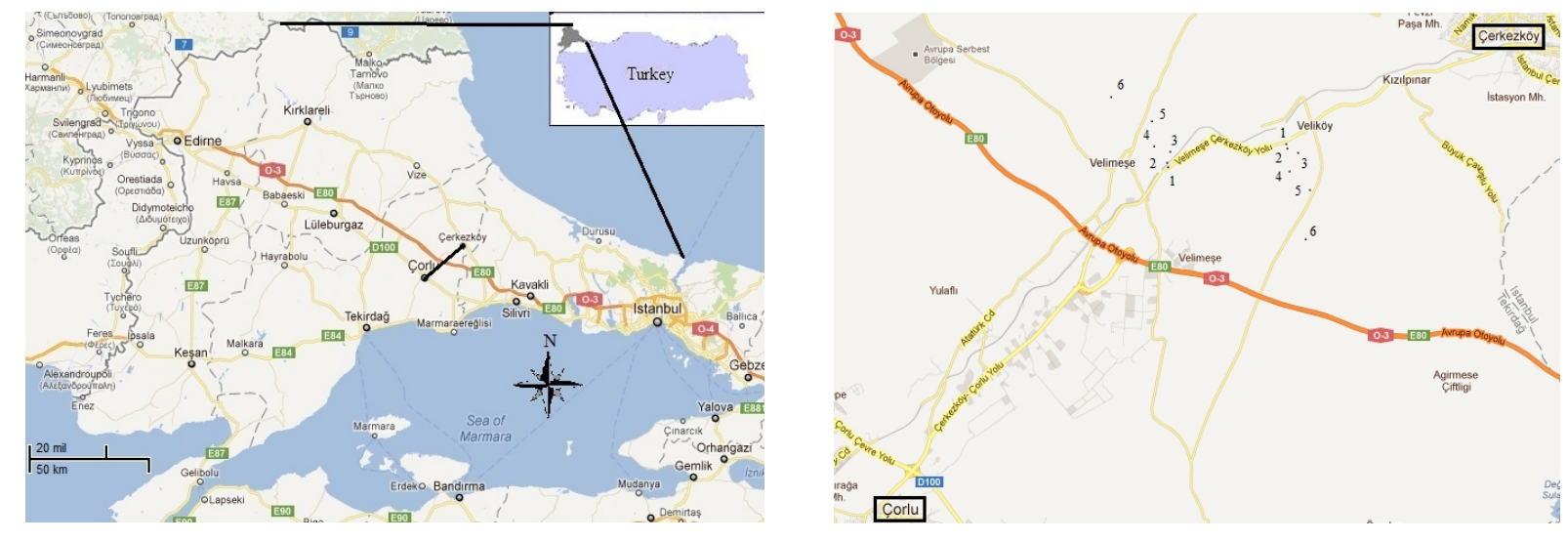

Figure 1. The map of study area and the sampling point

Geologically, the study area which is over sediments of the Istranca Masses is located in Paleozoic basin, within the metamorphic sedimentary rocks (Arkoç and Erdogan, 2006). Mediterranean climatic conditions prevail in the study area. The average annual precipitation is $662.3 \mathrm{~mm}$ and the average annual temperature is $13.7^{\circ} \mathrm{C}$. North and Northeast wind dominant in studied area.

\subsection{Soil and Plant Sampling}

A total of thirty six soil samples were randomly collected $(0-200 \mathrm{~mm}$ depth) for sampling location. From 12 sampling points, thirty six soil samples $(0-200 \mathrm{~mm}$ depth) were collected at different distance of $1,25,50,100,250$ and $500 \mathrm{~m}$ on a line to the north and south of highway in May. Three composite soil samples were collected from each sampling point. Soil samples were air-dried, passed through a $2.00 \mathrm{~mm}$ (10 meshes) sieve and stored in plastic bags.

A total of thirty six plant samples were randomly collected at the same distances as mentioned above from 12 sampling points along the highway. For all plant samples were divided into two parts. One part of these samples was washed by distilled water and then deionized water to remove any 
particulates. The other plant samples were analyzed without any washing. A composite sample which included stem, roots, leaves, grain was analyzed in all together. Washed and unwashed plant samples were stored plastic bags in refrigerator for subsequent analysis. All plant samples were analyzed in duplicates.

\subsection{Reagents and Apparatus}

The standard working metal solutions of $\mathrm{Pb}, \mathrm{Zn}, \mathrm{Cd}, \mathrm{Cu}, \mathrm{Ni}, \mathrm{Mn}, \mathrm{Cr}$ and Fe were prepared by step dilution of standard stock solutions (1000 mg L-1 Merck AAS solutions) with double distilled deionized water. In order to eliminate contamination, all containers were dipped in concentrated $\mathrm{HNO}_{3}$ over a night and rinsed with distilled water prior to use.

A Perkin Elmer 300 Zeeman atomic absorption spectrometer equipped with an HGA-800 graphite furnace and an auto sampler was used to determine the elemental composition of the samples. The graphite furnace temperature program for working elements were set of as recommended by the manufacturer. A Unicam model 929 AA flame atomic absorption spectrometer with deuterium lamp and air acetylene burner was used during analyses. The operating parameters for working elements were set as recommended by manufacturer.

\subsection{Procedures}

Briefly, analysis of $\mathrm{pH}$ and EC were conducted using an electronic potentiometer in a 1:2.5 soil/water mixture (Jackson, 1975). $\mathrm{CaCO}_{3} \%$ was measured by using calcimeter (Kacar, 1996). The organic matter was determined after extraction with potassium dichromate digestion. Then the soil was titrated with iron (II) sulphate solution using phenanthroline indicator (Walkley and Black, 1947), the granulometric characterization was performed following hydrometer method (Bouyoucos, 1951). The soil samples were carried out based on the methods mentioned.

The method developed by Kacar, (1996) was used in soil sample digestion and heavy metal analysis. This method was appropriate for the soils of study area. In the digestion of soil, $2.0 \mathrm{~g}$ sample was digested with $30 \% \mathrm{H}_{2} \mathrm{O}_{2}(10 \mathrm{~mL})$, and then dried at $90{ }^{\circ} \mathrm{C}$. This process was repeated twice, and three drops of concentrated $\mathrm{H}_{2} \mathrm{SO}_{4}$ and $10 \mathrm{~mL}$ concentrated $\mathrm{HF}$ were added to dried samples. Then, samples were dried at $200{ }^{\circ} \mathrm{C}$. $15 \mathrm{~mL}$ concentrated $\mathrm{HNO}_{3}, 2 \mathrm{~mL}$ concentrated $\mathrm{H}_{2} \mathrm{SO}_{4}$ and $1 \mathrm{~mL}$ concentrated $\mathrm{HClO}_{4}$ were added to the dried samples. Following the cooling of samples, $25 \mathrm{~mL}$ distilled water was added to samples. The residue was filtered and diluted to $50 \mathrm{~mL}$ with distilled water. The concentrations of $\mathrm{Zn}, \mathrm{Cr}, \mathrm{Cu}, \mathrm{Ni}, \mathrm{Mn}$ and $\mathrm{Fe}$ were determined by FAAS (Unicam model $929 \mathrm{AA}$ ), and concentrations of $\mathrm{Pb}$ and $\mathrm{Cd}$ were determined by GFAAS in the Kırklareli Laboratory of Agricultural Research Institue of Soil and Water Resources.

The each plant samples were divided into subsamples. Each subsample was washed with distilled water and dried at $105{ }^{\circ} \mathrm{C}$ for $30 \mathrm{~min}$ and $60{ }^{\circ} \mathrm{C}$ for $24 \mathrm{~h}$. While other subsample of plant was dried without washing. The rest of the plant materials were only dried at the same temperatures. All dried plant samples were ground, homogenized and were stored in plastic bags. For the digestion of plant materials, $1.0 \mathrm{~g}$ sample was placed into an Erlenmeyer and digested for $3 \mathrm{~h}$ at $85{ }^{\circ} \mathrm{C}$ with concentrated $\mathrm{HNO}_{3}: \mathrm{HCl}(3: 1)$ mixture. $1 \mathrm{~mL}$ concentrated $\mathrm{HClO}_{4}$ was added to mixture (Şabudak et al., 2007). The solutions were filtered and diluted to $50 \mathrm{~mL}$ with distilled water. The concentrations of $\mathrm{Pb}, \mathrm{Cd}, \mathrm{Zn}, \mathrm{Cr}, \mathrm{Cu}, \mathrm{Ni}, \mathrm{Mn}$ and $\mathrm{Fe}$ in plant samples were determined by GFAAS.

\subsection{Quality Control}

The accuracy and precision of the analysis results were checked by periodic analysis of Standard Reference Materials obtained from the Country Control Laboratory of Agriculture Ministry. The percent recovery for the soil sample for $\mathrm{Pb}, \mathrm{Zn}, \mathrm{Cd}, \mathrm{Cu}, \mathrm{Ni}, \mathrm{Mn}, \mathrm{Cr}$ and $\mathrm{Fe}$ were 95, 94, 96, 95.4, 95, 97, 94 and 95, respectively. The percent recovery of wheat plants for $\mathrm{Pb}, \mathrm{Zn}, \mathrm{Cd}, \mathrm{Cu}, \mathrm{Ni}, \mathrm{Mn}, \mathrm{Cr}$ and Fe were 96, 100, 96, 97, 102, 93, 94 and 97, respectively. Blank and standard solutions were used to calibrate the instruments. The $r^{2}$ values were $0.9994,0.9995,0.9996,0.9997,0.9992,0.9999$, 0.9991 and 0.9998 for $\mathrm{Pb}, \mathrm{Zn}, \mathrm{Cd}, \mathrm{Cu}, \mathrm{Ni}, \mathrm{Mn}, \mathrm{Cr}$ and Fe, respectively.

\subsection{Statistical Analysis}

Means and standard deviations were used to assess the contamination levels of heavy metals in soil and plant samples. Linear regression analysis was conducted to determine the relationships between heavy metal concentration and effect of sampling distance. The analyses were performed using TARIST software. 


\section{RESULTS}

\subsection{Metal Concentrations in Soil Samples}

A number of factors govern the extent of heavy metal accumulation and distribution in soil and plants. Factors include the distance of the sample from highway, the soil chemical and physical properties such as $\mathrm{pH}$, organic matter, clay content, wind direction, car density of the road, and duration of exposure (Kalavrouziotis et al., 2007a). According to Haktanir (1983) and Redondo et al. (2009) the amount of organic matter, $\mathrm{pH}, \mathrm{CaCO}_{3} \%$ and texture of soil affects on the heavy metal accumulation. The heavy metal is adsorbed by organic matter and silt/clay fraction. The high $\mathrm{pH}$, organic matter and clay content increase the binding of heavy metals.

Some of physical and chemical properties of investigated soils were given in Table 1. Organic matter content of the soils studied was low. The amount of $\mathrm{CaCO}_{3}$ was very low. The pH's soils were between 7.1 and 7.5, and therefore considered as neutral. According to the percentages of sand, silt and clay, the soils investigated were classified, in north, as sandy clay loam; in south, as sandy loam.

Table 1. Soil characteristics of the study area

\begin{tabular}{ccccccccc}
\hline & $\begin{array}{c}\mathrm{EC} \\
\mathrm{dS} \mathrm{m}\end{array}$ & $\mathrm{pH}$ & $\begin{array}{c}\text { Organic matter } \\
\%\end{array}$ & $\begin{array}{c}\mathrm{CaCO} 3 \\
\%\end{array}$ & $\begin{array}{c}\text { Sand } \\
\%\end{array}$ & $\begin{array}{c}\text { Loam } \\
\%\end{array}$ & $\begin{array}{c}\text { Clay } \\
\%\end{array}$ & Texture \\
\hline North & 0.186 & 7.5 & 1.71 & 1.91 & 57.2 & 15.4 & 27.4 & $\mathrm{SCL}^{*}$ \\
South & 0.128 & 7.1 & 1.53 & 0.48 & 61.0 & 23.4 & 15.6 & $\mathrm{SL}^{* *}$ \\
\hline
\end{tabular}

*Sandy-clay-loam $\quad{ }^{* *}$ Sandy-loam

The total heavy metal contents determined according to directions and distances from highway were shown in Table 2. According to the results in Table 2, the highest Zn $59 \pm 0.6 \mathrm{mg} \mathrm{kg}^{-1}$, Cu $39 \pm 0.6 \mathrm{mg}$ $\mathrm{kg}^{-1}$ and $\mathrm{Cd} 0.34 \pm 0.4 \mathrm{mg} \mathrm{kg}^{-1}$ concentrations were placed within the normal levels in agricultural soils. Copper is usually reported to dominate in the organic and residual phases (Harrison et al., 1981). Metamorphic sedimentary rocks constitute the parent material of the study area (Arkoç and Erdogan, 2006).

The maximum $\mathrm{Pb}$ concentrations in the north and south, $230 \pm 0.5 \mathrm{mg} \mathrm{kg}^{-1}$ and $351 \pm 0.3 \mathrm{mg} \mathrm{kg}^{-1}$ were measured at distances of $25 \mathrm{~m}$ and $100 \mathrm{~m}$ from the access highway, respectively. The dominant wind has likely carried $\mathrm{Pb}$ to those sampling points. The soil samples had highly $\mathrm{Pb}$ concentrations of 10-14 times that of the average agricultural soils explained by Kacar (1996). This is result of the traffic pollution and the industrialization. Major source of $\mathrm{Pb}$ is the combustion of diesel/petrol, the vessel of the car. This finding is similar to those found by Adiloğlu et al. (2011). The concentrations of $\mathrm{Pb}$ in most of the soil samples were higher than those recommended by the World Health Organization (WHO) $\mathrm{Pb}<35 \mathrm{mg} \mathrm{kg}^{-1}$ (Backison et al., 2006).

Table 2. The average heavy metals concentrations in soil samples ( $\mathrm{mg} \mathrm{kg}^{-1} \mathrm{dry}$ soil)

\begin{tabular}{|c|c|c|c|c|c|c|c|c|c|c|}
\hline \multirow{2}{*}{ Direction } & \multirow{2}{*}{$\begin{array}{c}\text { Sampling } \\
\text { point }\end{array}$} & \multirow[b]{2}{*}{$(\mathrm{m})$} & \multicolumn{6}{|c|}{ Concentration $^{*}, \mathrm{mg} \mathrm{kg}^{-1}$} & \multirow[b]{2}{*}{$\mathrm{Cr}$} & \multirow[b]{2}{*}{$\mathrm{Fe}$} \\
\hline & & & $\mathrm{Zn}$ & $\mathrm{Cu}$ & $\mathrm{Cd}$ & $\mathrm{Pb}$ & $\mathrm{Ni}$ & $\mathrm{Mn}$ & & \\
\hline \multirow{6}{*}{ North } & 1 & 1 & $47 \pm 0.8$ & $18 \pm 0.5$ & $0.34 \pm 0.4$ & $19 \pm 0.2$ & $28 \pm 1.4$ & $234 \pm 0.5$ & $86 \pm 0.3$ & $7637 \pm 0.2$ \\
\hline & 2 & 25 & $35 \pm 1.1$ & $20 \pm 0.9$ & $0.24 \pm 0.5$ & $230 \pm 0.5$ & $2.6 \pm 0.9$ & $204 \pm 0.8$ & $108 \pm 0.3$ & $7236 \pm 0.2$ \\
\hline & 3 & 50 & $48 \pm 0.7$ & $20 \pm 0.8$ & $0.25 \pm 0.5$ & $27 \pm 0.3$ & $12 \pm 1.1$ & $298 \pm 0.9$ & $94 \pm 0.8$ & $6719 \pm 0.5$ \\
\hline & 4 & 100 & $37 \pm 0.9$ & $16 \pm 0.7$ & $0.32 \pm 0.7$ & $159 \pm 0.5$ & $1 \pm 0.5$ & $391 \pm 0.2$ & $74 \pm 1.3$ & $7342 \pm 0.3$ \\
\hline & 5 & 250 & $43 \pm 0.5$ & $16 \pm 0.5$ & $0.18 \pm 0.8$ & $76 \pm 0.3$ & $26 \pm 0.4$ & $182 \pm 0.1$ & $100 \pm 0.2$ & $7508 \pm 0.4$ \\
\hline & 6 & 500 & $59 \pm 0.6$ & $15 \pm 0.5$ & $0.28 \pm 0.7$ & $135 \pm 0.4$ & $46 \pm 0.5$ & $384 \pm 0.6$ & $77 \pm 0.1$ & $6205 \pm 0.1$ \\
\hline \multirow{6}{*}{ South } & 1 & 1 & $46 \pm 0.5$ & $30 \pm 0.4$ & $0.20 \pm 0.5$ & $72 \pm 0.5$ & $35 \pm 0.2$ & $251 \pm 0.1$ & $106 \pm 0.3$ & $9230 \pm 0.8$ \\
\hline & 2 & 25 & $35 \pm 0.3$ & $33 \pm 0.5$ & $0.20 \pm 0.9$ & $99 \pm 0.4$ & $30 \pm 0.4$ & $380 \pm 0.2$ & $43 \pm 0.6$ & $2528 \pm 0.3$ \\
\hline & 3 & 50 & $35 \pm 0.8$ & $39 \pm 0.2$ & $0.29 \pm 0.6$ & $39 \pm 0.7$ & $8.4 \pm 0.6$ & $473 \pm 0.2$ & $23 \pm 0.8$ & $7750 \pm 0.4$ \\
\hline & 4 & 100 & $37 \pm 0.9$ & $24 \pm 0.7$ & $0.32 \pm 0.3$ & $351 \pm 0.3$ & $3.9 \pm 0.8$ & $806 \pm 0.1$ & $21 \pm 0.7$ & $7661 \pm 0.5$ \\
\hline & 5 & 250 & $30 \pm 0.5$ & $30 \pm 0.6$ & $0.17 \pm 0.7$ & $27 \pm 0.3$ & $8.8 \pm 0.4$ & $389 \pm 0.3$ & $55 \pm 0.6$ & $3727 \pm 0.9$ \\
\hline & 6 & 500 & $57 \pm 0.5$ & $39 \pm 0.6$ & $0.29 \pm 0.5$ & $42 \pm 0.2$ & $13.0 \pm 0.2$ & $424 \pm 0.4$ & $142 \pm 0.5$ & $8541 \pm 1.1$ \\
\hline
\end{tabular}

Mean value \pm standard deviation " Values from three replicates $(n=3)$ 
The manganese levels of soils were slightly high and varied from $182 \pm 0.1 \mathrm{mg} \mathrm{kg}^{-1}$ to $806 \pm 0.1 \mathrm{mg} \mathrm{kg}^{-1}$. Similar concentrations of $\mathrm{Mn}$ in soil were reported by Tayel et al. (2006) and Jaradat et al. (2005). $\mathrm{Mn}$ and $\mathrm{Ni}$ are fuel additives as is $\mathrm{Pb}$, especially in burning fuels (diesel) that are used in residential heating system. The concentrations of $\mathrm{Ni} 1 \pm 0.5 \mathrm{mg} \mathrm{kg}^{-1}$ to $46 \pm 0.5 \mathrm{mg} \mathrm{kg}^{-1}$ measured in all soil samples remained within the natural limits in soils. The concentration of $\mathrm{Ni}$ in soil is similar to those found by Fabis, (1987). Ni and $\mathrm{Pb}$ concentrations are very variable from a sampling point to another. Not only the dominant wind but also industrial activities in the study area can probably lead to this result. Moreover, $\mathrm{Cr}$ concentration was slightly high in the south at a distance $500 \mathrm{~m}$ from highway. The concentration of $\mathrm{Cr}$ was measured in all soil samples as $142 \pm 0.5 \mathrm{mg} \mathrm{kg}^{-1}$ to $21 \pm 0.7 \mathrm{mg} \mathrm{kg}^{-1}$ at 1 and $500 \mathrm{~m}$ distances from the road. This finding appeared to be consistent with the results from other studies (Kelly et al., 1996; Shallari et al., 1998; Feng-Rui et al., 2007). The maximum Fe levels were observed in the south at a distance $1 \mathrm{~m}$ from the highway with $9230 \pm 0.8 \mathrm{mg} \mathrm{kg}{ }^{-1}$. The concentrations of $\mathrm{Fe}$ in soils were slightly high.

The regression analyses showed that concentration of heavy metals versus distance were not significant. This may be explained by the fact that the area contains the industrial activities as well. Nevertheless, reductions were detected in the concentrations of $\mathrm{Cu}, \mathrm{Cd}, \mathrm{Cr}$ and $\mathrm{Fe}$ with distance in the northern side, and those of $\mathrm{Pb}, \mathrm{Ni}$ with distance in the southern side.

\subsection{Metal Concentrations in Plants}

Cereals are essential constituents of the human diet. Wheat plant (Triticum aestivum L.) was chosen to test heavy metal contamination because of approximately $65 \%$ Turkey's wheat is produced on the agricultural sites of the Thrace region. Roots, leaves, grain and stem of wheat plant were used in the analyses. The heavy metal concentrations obtained from washed and unwashed wheat samples are given in Table 3.

Heavy metal concentrations at different distances were different in the washed and in unwashed plant samples. This is a result of the impact of atmospheric fall. For unwashed samples, the total concentrations of heavy metals represent the amount deposited on the plant surface by atmospheric dust fall. The heavy metal concentrations of unwashed plant samples were higher than those of the washed ones. Furthermore, linear regression between unwashed versus washed was significant in $\mathrm{Cu}, \mathrm{Ni}, \mathrm{Mn}$ and $\mathrm{Fe}$. In the unwashed plant samples, maximum concentrations of $\mathrm{Zn} 34 \pm 0.2 \mathrm{mg} / \mathrm{kg}$, $\mathrm{Pb} 5.3 \pm 0.8 \mathrm{mg} / \mathrm{kg}$, Ni $45 \pm 0.4 \mathrm{mg} / \mathrm{kg}, \mathrm{Mn} 397 \pm 5.1 \mathrm{mg} / \mathrm{kg}$ and $\mathrm{Fe} 481 \pm 2.3 \mathrm{mg} / \mathrm{kg}$ were observed at a distance of $250 \mathrm{~m}$ to $500 \mathrm{~m}$ to the south of highway. Plant uptake of heavy metals from soil occurs either passively with the mass flow of water into the roots or through active transport crossing the plasma membrane of roots epidermal cells (Kim et al., 2003). According to Kalavrouziotis et al., (2007a), higher levels of heavy metals have accumulated in the roots of Zea mays than the leaves. Metal uptake by plants is controlled not only by metal interactions at the level of soil cation exchange sites, but also by competition at root sites of absorption.

The metal accumulation in unwashed samples was compared also with the common levels for heavy metals in plants (Table 4). In the present study, none of the concentration of the heavy metals studied exceeded the phytotoxic levels. All of the metals in plant samples, except for $\mathrm{Mn}$, were present within normal concentration levels. This finding appeared to be consistent with the result from the study of Kalavrouziotis et al., (2007a) and Jaradat et al., (2005). The Mn concentrations in plants were slightly high similar to those found by Pugh et al., (2002) and by Chaney, (1989).

The $\mathrm{Cd}$ and $\mathrm{Cr}$ contents in plant samples were determined to be at trace levels. The $\mathrm{Cu}$ concentrations in the washed and unwashed wheat close to each other.

According to the regression analysis, coefficients of the heavy metals versus distance and unwashed-washed relations are shown in Table 5. Significant negative relationships were observed between heavy metal concentrations and distance: unwashed $\mathrm{Zn}\left(R^{2}=-0.990 ; P<0.01\right), \mathrm{Cu}\left(R^{2}=-\right.$ 0.906; $P<0.05), \mathrm{Ni}\left(R^{2}=-0.833 ; P<0.01\right), M n\left(R^{2}=-0.940 ; P<0.01\right)$, washed $M n\left(R^{2}=-0.930 ; P<0.01\right)$ in north.

This investigation clearly showed (Figure 2) that the heavy metal concentration decreased with increasing distances from the highway in unwashed plants. These results are similar to those found by Kalavrouziotis et al. (2006). 
Table 3. The average heavy metals concentrations in plant samples ( $\mathrm{mg} \mathrm{kg}^{-1}$ dry plant)

\begin{tabular}{|c|c|c|c|c|c|c|c|c|c|}
\hline \multirow{2}{*}{$\begin{array}{c}\text { Wheat } \\
\text { plant }\end{array}$} & \multirow[b]{2}{*}{ Direction } & \multirow{2}{*}{$\begin{array}{c}\text { Sampling } \\
\text { Point }\end{array}$} & \multirow{2}{*}{$\begin{array}{c}\text { Distance } \\
(\mathrm{m})\end{array}$} & \multicolumn{2}{|r|}{ Conc. ${ }^{*}$} & $\mathrm{mg} \mathrm{kg}^{-1}$ & & \multirow[b]{2}{*}{$\mathrm{Fe}$} & \multirow[b]{2}{*}{$\mathrm{Cu}$} \\
\hline & & & & $\mathrm{Zn}$ & $\mathrm{Pb}$ & $\mathrm{Ni}$ & $\mathrm{Mn}$ & & \\
\hline & & 1 & 1 & $20 \pm 0.4$ & $1.0 \pm 0.2$ & $20 \pm 1.2$ & $115 \pm 0.8$ & $381 \pm 2.3$ & $8.2 \pm 0.2$ \\
\hline & & 2 & 25 & $18 \pm 0.8$ & $1.7 \pm 0.1$ & $13 \pm 1.7$ & $114 \pm 3.2$ & $273 \pm 1.4$ & $7.3 \pm 0.9$ \\
\hline \multirow[t]{6}{*}{ Unwashed } & North & 3 & 50 & $16 \pm 0.7$ & $1.7 \pm 0.3$ & $9.0 \pm 0.4$ & $110 \pm 2.4$ & $151 \pm 1.7$ & $7.1 \pm 1.4$ \\
\hline & & 4 & 100 & $16 \pm 0.9$ & $1.4 \pm 0.3$ & $7.0 \pm 0.6$ & $99 \pm 0.9$ & $149 \pm 1.2$ & $6.4 \pm 2.3$ \\
\hline & & 5 & 250 & $11 \pm 1.7$ & $1.3 \pm 0.9$ & $8.0 \pm 0.4$ & $88 \pm 1.9$ & $148 \pm 2.1$ & $6.4 \pm 0.9$ \\
\hline & & 6 & 500 & $4.0 \pm 0.6$ & $0.8 \pm 0.7$ & $0.1 \pm 0.4$ & $81 \pm 4.4$ & $115 \pm 0.9$ & $5.2 \pm 0.5$ \\
\hline & & 1 & 1 & $19 \pm 0.9$ & $0.9 \pm 0.4$ & $10 \pm 0.4$ & $110 \pm 2.2$ & $341 \pm 4.5$ & $8.0 \pm 0.7$ \\
\hline & & 2 & 25 & $9.0 \pm 1.0$ & $1.5 \pm 0.5$ & $7.0 \pm 0.9$ & $99 \pm 2.8$ & $212 \pm 3.5$ & $7.5 \pm 0.4$ \\
\hline \multirow[t]{6}{*}{ Washed } & North & 3 & 50 & $6.0 \pm 0.7$ & $0.9 \pm 0.2$ & $4.0 \pm 0.4$ & $92 \pm 0.9$ & $195 \pm 2.1$ & $6.9 \pm 0.4$ \\
\hline & & 4 & 100 & $5.0 \pm 0.7$ & $0.7 \pm 0.2$ & $2.0 \pm 0.6$ & $88 \pm 1.3$ & $148 \pm 0.9$ & $6.8 \pm 1.1$ \\
\hline & & 5 & 250 & $4.0 \pm 0.4$ & $0.9 \pm 0.1$ & $0.1 \pm 0.1$ & $49 \pm 1.2$ & $148 \pm 4.3$ & $6.4 \pm 0.5$ \\
\hline & & 6 & 500 & $1.0 \pm 0.6$ & $0.6 \pm 0.1$ & $0.1 \pm 0.1$ & $43 \pm 0.4$ & $115 \pm 7.6$ & $6.4 \pm 0.2$ \\
\hline & & 1 & 1 & $19 \pm 0.8$ & $2.6 \pm 0.3$ & $0.2 \pm 0.1$ & $160 \pm 1.4$ & $116 \pm 5.6$ & $6.7 \pm 1.2$ \\
\hline & & 2 & 25 & $21 \pm 0.6$ & $3.8 \pm 0.4$ & $12 \pm 0.4$ & $178 \pm 0.6$ & $242 \pm 5.8$ & $6.7 \pm 3.2$ \\
\hline \multirow[t]{6}{*}{ Unwashed } & South & 3 & 50 & $24 \pm 0.5$ & $2.8 \pm 0.4$ & $22 \pm 0.7$ & $182 \pm 3.2$ & $305 \pm 1.5$ & $7.0 \pm 0.4$ \\
\hline & & 4 & 100 & $25 \pm 0.5$ & $5.2 \pm 0.6$ & $31 \pm 0.6$ & $211 \pm 0.9$ & $343 \pm 0.9$ & $7.1 \pm 0.2$ \\
\hline & & 5 & 250 & $34 \pm 0.2$ & $1.6 \pm 0.8$ & $45 \pm 0.4$ & $397 \pm 5.1$ & $403 \pm 0.7$ & $7.5 \pm 0.1$ \\
\hline & & 6 & 500 & $33 \pm 1.3$ & $5.3 \pm 0.8$ & $3.0 \pm 0.9$ & $177 \pm 4.8$ & $481 \pm 2.3$ & $7.8 \pm 0.1$ \\
\hline & & 1 & 1 & $10 \pm 1.7$ & $1.2 \pm 0.9$ & $0.1 \pm 0.2$ & $49 \pm 0.7$ & $112 \pm 0.6$ & $6.7 \pm 0.3$ \\
\hline & & 2 & 25 & $10 \pm 0.9$ & $1.3 \pm 0.3$ & $12 \pm 0.4$ & $108 \pm 1.1$ & $204 \pm 6.1$ & $7.0 \pm 1.4$ \\
\hline \multirow[t]{4}{*}{ Washed } & South & 3 & 50 & $13 \pm 0.1$ & $1.6 \pm 0.7$ & $22 \pm 0.4$ & $119 \pm 2.0$ & $291 \pm 1.2$ & $7.1 \pm 0.6$ \\
\hline & & 4 & 100 & $14 \pm 0.7$ & $4.0 \pm 0.7$ & $31 \pm 0.7$ & $126 \pm 3.6$ & $343 \pm 0.7$ & $7.1 \pm 0.2$ \\
\hline & & 5 & 250 & $15 \pm 1.6$ & $4.0 \pm 0.4$ & $37 \pm 0.5$ & $144 \pm 1.9$ & $400 \pm 5.3$ & $7.5 \pm 0.4$ \\
\hline & & 6 & 500 & $24 \pm 1.2$ & $1.6 \pm 0.4$ & $0.1 \pm 0.2$ & $92 \pm 1.2$ & $136 \pm 2.7$ & $7.8 \pm 0.6$ \\
\hline
\end{tabular}

Table 4. Typical levels for heavy metals in plants (Pugh et al., 2002)

\begin{tabular}{cccccc}
\hline \multirow{2}{*}{ Element } & \multicolumn{5}{c}{ Concentration, $\mathrm{mg} \mathrm{kg}^{-1}$} \\
\cline { 2 - 6 } & $\mathrm{Pb}$ & $\mathrm{Cd}$ & $\mathrm{Zn}$ & $\mathrm{Mn}^{*}$ & $\mathrm{Cu}$ \\
\hline Deficient & --- & -- & $<10$ & -- & $<1-5$ \\
Normal & $0.5-10$ & $0.05-2$ & $10-150$ & $15-150$ & $3-30$ \\
Phytotoxic & $30-300$ & $5-700$ & $>100$ & $400-2000$ & $20-100$ \\
\hline
\end{tabular}

${ }^{*}$ Concentrations were adopted from Chaney (1989). 
Table 5. Heavy metal concentrations in plant versus distance and unwashed-washed relations

\begin{tabular}{lccccccc}
\hline Distance $(\mathrm{m})$ & & $\mathrm{Zn}$ & $\mathrm{Cu}$ & $\mathrm{Pb}$ & $\mathrm{Ni}$ & $\mathrm{Mn}$ & $\mathrm{Fe}$ \\
\hline \multirow{2}{*}{$1-25-50$} & Unwashed N & $-0.990^{* *}$ & $-0.906^{*}$ & $-0.643 \mathrm{~ns}$ & $-0.833^{* *}$ & $-0.940^{* *}$ & $-0.648 \mathrm{~ns}$ \\
\multirow{2}{*}{$100-250-500$} & Washed N & $-0.709 \mathrm{~ns}$ & $-0.763 \mathrm{~ns}$ & $-0.574 \mathrm{~ns}$ & $-0.768 \mathrm{~ns}$ & $-0.930^{* *}$ & $-0.705 \mathrm{~ns}$ \\
& Unwashed S & $0.873^{*}$ & $0.958^{* *}$ & $0.365 \mathrm{~ns}$ & $-0.012 \mathrm{~ns}$ & $0.248 \mathrm{~ns}$ & $0.866^{*}$ \\
& Washed S & $0.970^{* *}$ & $0.952^{* *}$ & $0.160 \mathrm{~ns}$ & $-0.131 \mathrm{~ns}$ & $0.155 \mathrm{~ns}$ & $-0.065 \mathrm{~ns}$ \\
\hline Unwashed/Washed & $\mathrm{N}$ & $0.783 \mathrm{~ns}$ & $0.898^{*}$ & $0.021 \mathrm{~ns}$ & $0.917^{*}$ & $0.967^{* *}$ & $0.950^{* *}$ \\
& $\mathrm{~S}$ & $0.800 \mathrm{~ns}$ & $0.965^{* *}$ & $0.454 \mathrm{~ns}$ & $0.986^{* *}$ & $0.676 \mathrm{~ns}$ & $0.370 \mathrm{~ns}$ \\
\hline ns: not significant & $* \cdot \mathrm{P}<0.05$ & $* * * \mathrm{P}<0.01$ & $\mathrm{~N} \cdot$ NorthS: South & &
\end{tabular}

ns: not significant $\quad *: P<0.05 \quad$ ** $: P<0.01 \quad N$ : NorthS: South
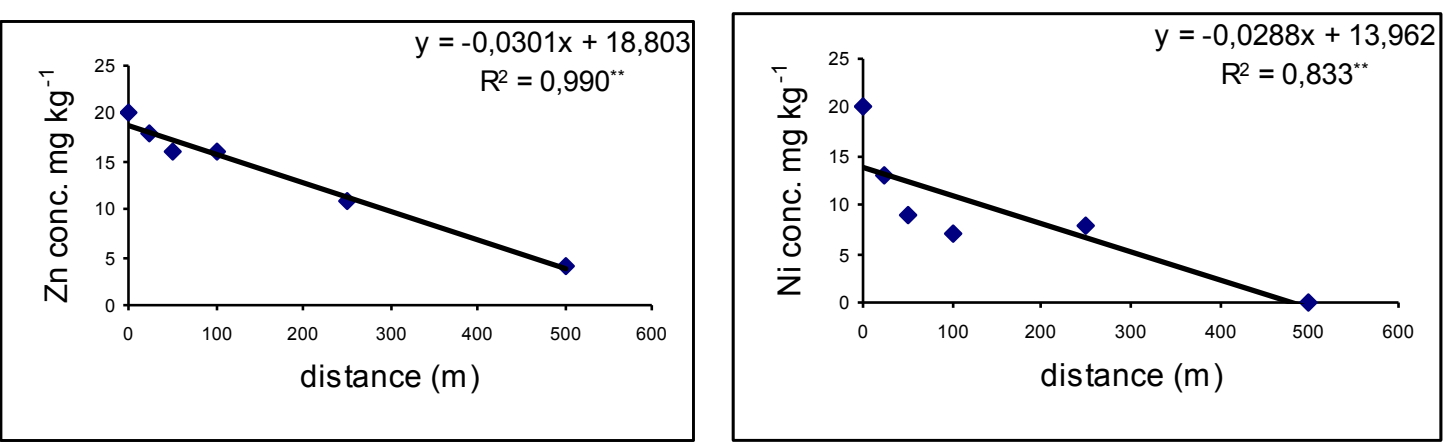

Figure 2. Zn concentration-distance and $\mathrm{Ni}$ concentration-distance relations in unwashed plants

In contrast, significant positive relationships were observed between heavy metal concentrations and distance: unwashed plant $Z n\left(R^{2}=0.873 ; P<0.05\right), \mathrm{Cu}\left(R^{2}=0.958 ; P<0.01\right), \mathrm{Fe}\left(R^{2}=0.866 ; P<0.05\right)$, washed $\mathrm{Zn}\left(R^{2}=0.970 ; P<0.01\right), \mathrm{Cu}\left(R^{2}=0.952 ; P<0.01\right)$ in south. The emission of factories located in the south might have caused these positive relationships. The atmospheric depositions can also cause heavy metal contamination of plants. Similarly, the study of Feng-Rui et al., (2007) reported that $\mathrm{Zn}, \mathrm{Pb}$ and $\mathrm{Cu}$ concentrations were generally controlled by anthropogenic activities (including traffic activities), whereas Co and Ni had natural origins.

Significant relationships were observed between unwashed and washed: $\mathrm{Cu}\left(R^{2}=0.898 ; P<0.05\right), \mathrm{Ni}$ $\left(R^{2}=0.917 ; P<0.05\right), M n\left(R^{2}=0.967 ; P<0.01\right)$ Fe $\left(R^{2}=0.950 ; P<0.01\right)$ in north and $\mathrm{Cu}\left(R^{2}=0.965\right.$ $P<0.01), \mathrm{Ni}\left(R^{2}=0.986 ; P<0.01\right)$ in south. Results indicate that the heavy metal contents decreased with washing and their deposition on plants are similar to those reported by Rains (1971) and Buchauer (1973).

\section{CONCLUSION}

In this study, concentration of $\mathrm{Pb}$ was found to be higher than the allowable maximum limits in soils. The high $\mathrm{Pb}$ and slightly high $\mathrm{Mn}$ show that heavy metal contamination at the soil of study area. The concentrations of $\mathrm{Cu}, \mathrm{Ni}, \mathrm{Mn}$ and $\mathrm{Fe}$ in unwashed wheat plants were statistically higher than those of the washed wheat plants. This is a result of the impact of traffic pollution on wheat plants. The results of the present work indicate that the heavy metals originated from the traffic precipitates in the plant samples. It was observed that the Mn concentration in unwashed wheat was higher than the normal levels however, being non toxic to the plant. The heavy metals which originated from motor vehicles have transported by the wind. Likewise, it was also observed that the maximum metal concentrations in soil and plants where are in the south of highway, except for $\mathrm{Cd}$ and $\mathrm{Ni}$ in the soil. This result has showed that the dominant wind (north and north-east) are carried the traffic pollutant to the south of area. These findings have demonstrated an apparent influence of traffic emission on wheat plants in close proximity to Corlu-Cerkezkoy Highway.

This study would help to reduce the risk to human health that originates from highway pollution. But, further extensive sampling is necessary to include similar study areas, and further research concerning contamination of other cereals. 


\section{ACKNOWLEDGEMENTS}

The authors thank the Trakya University (Project No: 698) and T.R. Ministry of Agriculture, the Kırklareli Laboratory of Agricultural Research Institue of Soil and Water Resources for supporting this study. Thanks are due to Mr. M. Barış Ekmekyapar of the Namık Kemal University, Department of Technical Sciences, for help in the sampling. Also thanks to Mr. Cihan Soydan of the Namık Kemal University, Department of Civil Engineering, for help in map drawing.

\section{REFERENCES}

Adiloğlu A., Adiloğlu S., Bellitürk K., Karakaş Ö., Sümer A., Gönülsüz E., Sari H., (2011). Tekirdağ Ili kıyı şeridi topraklarında ağır metal kirliliği. 1. Kıyı Bölgelerinde Çevre Kirliliği ve Kontrolu Sempozyumu, Tekirdag. 351-365 (in Turkish).

Arkoç O. and Erdogan M. (2006). Ergene Basin, Hydrogeochemistry of Çorlu-Çerkezköy land, ITU dergisi/d., 5, 125-134.

Backison D.T., Kwenga S. and Joseph C. (2006). Distribution of copper, lead, cadmium and zinc concentrations in soils around Kabwe town in Zambia, Chemosphere, 63, 497- 501.

Bouyoucos G.J. (1951). Arecalibration of the hydrometre for making mechanical analysis of soils, Agronomy Journal, 43, 434-438.

Buchauer M.J. (1973). Contamination of soil and vegetation near a zinc smelter by zinc, cadmium, copper and lead, Environ. Sci. Technol., 7, 132-134.

Chaney R.L. (1989). Toxic Element Accumulation in Soils and Crops: Protecting Soil Fertility and Agricultural Food-chains. In: Bar-Yozef B, Barrow N.I., Goldshmid J, Editors. Inorganic Contaminants in the Vadose Zone. Berlin: Springer-Verlag, Berlin, 140-158.

Charlesworth S., Everet M., McCarty R., Ordenez A. and DeMiguel E. A. (2003). Comparative study of heavy metal concentration and distribution in deposited street dusts in a large and a small urban area: Birmingham and Coventry. West Midlands, UK, Environ. Int., 29, 563-573.

Fabis W. (1987). Schadstoftbelastung Von Böden-Auswirkurgen auf Böden-und Wassergalitat Allg Farstzeitsehr. Münich: BLV Verlaggesellshaft, 128-131.

Feng-Rui L., Ling-Fen K., Xiao-Qing G., Wei H., Fa-Wang Y. and Wen-Long H. (2007). Traffic-Related heavy metal accumulation in soils and plants in Norwest China, Soil \& Sediment Contamin, 16, 473-484.

Haktanir K. (1983). Cevre Kirliligi, Ankara Un. Ziraat Fak. Yay., Ankara, Turkey (in Turkish).

Harrison R.M., Laxen D.P.H. and Wilson S.J. (1981). Chemical association of lead, cadmium, copper and zinc in street dust and roadside soil, Environ. Sci. Technol., 15, 1378-1383.

Jackson M.L. (1975). Soil Chemical Analysis, Prentice Hall Inc. Eng. Cliffs. University of Wisconsin, Madison, WI, 895.

Jamali M.K., Kazi T.G., Arain M.B., Afridi H.I., Jalbani N., Kandhro G.A., Shah A.Q., Baig J.A. (2009). Heavy metal accumulation in different varieties of wheat (Triticum aestivum L.) grown in soil amended with domestic sewage sludge, Journal of Hazardous Materials, 164 (2-3), 13861391.

Jaradat Q.M., Masadeh A., Zaitoun M.A. and Maitah B.M. (2005) Heavy metal contamination of soil, plant and air of scrapyard of discarded vehicles at Zarqa City, Jordan, Soil \& Sediment Contamin. 14, 449-462.

Kacar B. (1996). Toprak Analizleri, Ankara Universitesi Ziraat Fak Egitim Arastırma Gelistirme Vakfi Yay, Ankara, Turkey (in Turkish).

Kalavrouziotis I.K., Carter J., Varnavas S.P., Mehra, A. and Drakatos P.A. (2006). Towards an understanding of metal contamination in food and soils related to road traffic, Fresenius Environmental Bulletin, 15, 170-175.

Kalavrouziotis I.K., Carter J., Varnavas S.P., Mehra, A. and Drakatos P.A. (2007a). Towards an understanding of the effect of road pollution on adjacent food crops: Zea mays as an example, Int. J. Environ. and Pollut., 30(3/4), 576-592.

Kalavrouziotis I.K., Jones P., Carter J. and Varnavas S.P. (2007b). Uptake of trace metals by Lycopersicum esculendum $L$. at a site adjacent to the main road Athens-Thessaloniki, Greece, Fresenius Environmental Bulletin, 16, 133-139.

Kelly J., Thornton I. and Simpson P.R. (1996). Urban geochemistry: a study of influence of anthropogenic activity on heavy metal content of soils in traditionally industrial and non-industrial areas of Britain, Appl. Geochem., 11, 363-370. 
Kim I. S., Kang H.K., Johnson-Green P. and Lee E.J. (2003). Investigation of heavy metal accumulation in Polygonum thunbergiifor phytoextraction, Environ. Pollut., 126, 235-27.

Norrstrom A.C. and Jacks G. (1998). Concentrations and fractionation of heavy metals in roadside soils receiving de-icing salts, Sci. Total Environ., 218, 161-174.

Piron-Frenet M., Bureau F. and Pineau R. (1994). Lead accumulation in surface roadside soil:Its relationships to traffic density and meteorological parameters, Sci. Total Environ, 144, 297304.

Pugh R.E., Dick D.G. and Fredeen A.L. (2002). Heavy metal (Pb, Zn, Cd, Fe and Cu) contents of plant foliage near the Anvil Range Lead/Zinc mine, Faro, Yukon Territory, Ecotoxicol. Environ., 52, 273-279.

Rains D.W. (1971). Lead accumulation by wild oats (Avena fatua) in a contaminated area, Nature, $\mathbf{2 3 3}$, 210-211.

Redondo-Gomez S., Cantos M., Mateos-Naranjo E., Figueroa M.E. and Troncoso A. (2009). Heavy metals and trace element concentrations in intertidal soils of four estuaries of SW Iberian Peninsula, Soil \& Sediment Contamin, 18, 320-327.

Richards L.A. (1954). Diagnosis and Improvement of Saline and Alkali Soils. USDA, Handbook 60.

Şabudak T., Seren G., Kaykıoglu G. and Dinçer A.R. (2007). Determination of trace elements in soil and sunflower (Helianthus annuus L.) plant parts, Fresenius Environ. Bull. 16, 1274-1278.

Salah S.A. and Barrington S.F. (2006). Effect to soil fertility and transpiration rate on young wheat plants (Triticum aestivum) Cd/Zn uptake and yield, Agricultural Water Management, 82, 177-192.

Sezgin N., Ozcan H.K., Demir G., Nemlioglu S. and Bayat C. (2003). Determination of heavy metal concentrations in street dusts in Istanbul E-5 highway, Environ. Int., 29, 979-985.

Shallari S., Schwartz C., Hasko A. and Morel J.L. (1998). Heavy metals in soils and plants of Serpentine and industrial sites of Albani, Sci. Total Environ., 209, 133-18.

Tayel El-H., Mufeed B., Hamzeh, Al-O., Anf Z., Abdullah EL-A., Farah Al-N., Bruce W.B. and Anvar J. (2006). The distribution of heavy metals in urban street dust of Karak City, Jordan, Soil \& Sediment Contamin, 15, 357-365.

Turer D.G. and Maynard B.J. (2003). Heavy metal contamination in highway soils comparison of Corpus Christi, Texas and Cincinnati, Ohio shows organic matter is key to mobility, Clean Technol. Environ. Policy., 4, 235-245.

Viard B., Pihan F., Promeyrat S. and Pihan J.C. (2004). Integrated assessment of heavy metal (Pb, Zn, Cd) highway pollution: bioaccumulation in soil, Graminaceae and land snails, Chemosphere, 55, 1349-1359.

Walkley A. and Black L.A. (1934). An examination of the Degtjareff method for determining soil organic matter and a proposed modification of the chromic acid titration method, Soil Sci. 37, 29-38.

Yoon J., Cao X., Zhou Q. and Ma L.Q. (2006). Accumulation of $\mathrm{Pb}, \mathrm{Cu}$ and $\mathrm{Zn}$ in native plants growing on a contaminated Florida site, Sci. Total Environ., 368, 456-464. 